\title{
WANG SHOUREN'S ETHICO-EPISTEMOLOGY AND THE DOUBLE NATURE OF RECOGNITION
}

\author{
Jana S. ROŠKER \\ Department of Asian Studies, Faculty of Arts, Ljubljana University, \\ Aškerčeva 2, 1000 Ljubljana, Slovenia \\ jana.rosker@ff.uni-lj.si
}

\begin{abstract}
Wang Shouren 王守仁 (1472 - 1529), who appears more frequently in the history of Chinese philosophy under his pseudonym Wang Yangming 王陽明, is generally recognized as the most important exponent, indeed founder, of the Neo-Confucian "School of the Heart-Mind" (Xin xue 心 學). In the context of Neo-Confucianism, Wang's philosophy is of great importance, especially with regard to his views on the inseparable unity of ethics and epistemology and his latent syntheses of Confucian and Chan Buddhist thought. Within this framework, this article will provide a critical introduction to his epistemology, focusing on the innovative elements of his paradigm of the unity of knowledge and action (zhixing heyi 知行合一) and the underlying concept of innate knowledge (liangzhi 良知). For Wang, these two epistemological concepts were rooted in the human heartmind (xin 心) and possessed intense moral connotations that were reflected in practical ethics. On this ethico-epistemological basis, the paper will illuminate the methods of gradualism and subitism and critically address their connection to the Chan Buddhist view of gradual and instant enlightenment.
\end{abstract}

Keywords: Wang Shouren, Wang Yangming, Chinese ethico-epistemology, innate knowledge, liangzhi, unity of knowledge and action, zhixing heyi, gradualism, subitism

\section{Introduction: the Basic Tenets and the Historical Development of Classical Chinese Epistemology}

Although in Chinese classical discourses, just as in ancient European philosophy, there was no theory of knowledge as a precisely defined discipline, this does not mean that ancient Chinese thinkers did not deal with problems related to the process of perception and cognition, or with questions concerning the essence of knowledge and comprehension. However, the specifically Chinese approaches to 
these problems were generally quite different from those prevailing in discourses which later came to form the ideational templates of "European thought".

In China, inquiries into the issue of the origin of knowledge focused primarily on indirect comprehension, i.e. a comprehension which could be achieved through education and learning, while comprehension deriving from sensory perception and reasoning was regarded as only of secondary importance. According to many contemporary, transculturally aware epistemologists, ${ }^{1}$ the question of the nature of knowledge in the European tradition was nevertheless also treated in a very narrow way, namely as knowledge gained through reasoning, i.e. knowledge based on a scientific world view. Traditional Chinese thought understood this question in a very different way, i.e. as something which also (or primarily) stems from moral contents. Therefore, when we say that there was no theory of knowledge in traditional China, we mean that there was no European type of epistemology, or no epistemology understood in this narrow sense. ${ }^{2}$

According to Liao Xiaoping, ${ }^{3}$ classical Chinese and European thought also differ in their approaches to the theory of knowledge. The European approach is defined by a rational comprehension of the external objects of cognition, as well as by analysis and a strict separation of subject and object, while the classical Chinese epistemological discourses are defined by an intuitive method of inquiry. ${ }^{4}$ The Neo-Confucian discourses, especially the ones pertaining to the School of the heart-mind, have meticulously elaborated upon this method. This is by no means coincidental, for they have based their studies on the philosophy of Mencius, who strongly advocated introspection. ${ }^{5}$

The formal method which determined most of the theories found in the Chinese classics was based on the holistic world view, and the basic contents of these theories were rooted in the premises of pragmatic ethics. Since in this

\footnotetext{
${ }^{1}$ See for instance GONG, Z. Zhongguo gudai zhexue you mei you renshi lun 中國古代 哲學有沒有認識論? [Does Classical Chinese Philosophy Contain a Theory of Knowledge?]. In Guangxi minzu xиеуиап xиebao, 1996, Vol. 96, No. 3, p. 12.

${ }^{2}$ See for instance GONG, Z. Zhongguo gudai zhexue you mei you renshi lun 中國古代 哲學有沒有認識論? [Does Classical Chinese Philosophy Contain a Theory of Knowledge?]. In Guangxi minzu xиеуиап хиеbao, 1996, Vol. 96, No. 3, p. 12.

${ }^{3}$ LIAO, X. Lun Zhongguo chuantong zhexue daode renshilunde tezhi 論中國傳統哲學 道德認識論的特質 [On special Features of Traditional Chinese Moral Epistemology]. In Hebei Xuekan, 1994, Vol. 94, No. 4, p. 43.

${ }^{4}$ LIAO, X. Shilun xifang chuantong zhexue renshilunde jiben qubie 試論中西方傳統哲 學認識論的基本区別 [Basic Differences between the Chinese and Western Theory of Knowledge]. In Jinyang xuekan, 1994, Vol. 94, No. 2, p. 39.

${ }^{5}$ HU, X. The Relativity of Ren (Humaneness). In Asian Studies, 2021, Vol. 9, No. 1, p. 189.
} 
framework, real knowledge was always seen as moral knowledge, and since it was always necessarily applied within the network of ethical laws, such epistemology was inseparably linked to ethics. Hence, we could call this type of epistemology ethico-epistemology. This intrinsic connection between knowledge and value-bounded practice was particularly clearly visible in Wang Shouren's philosophy.

As already mentioned, Wang was a prominent member of the Neo-Confucian intellectual movement, and an heir to the conceptual schemes of his forerunners, the Neo-Confucian philosophers of the Song Dynasty $(960-1279) .{ }^{6}$ In this period, Chinese epistemology was beginning to develop in a more complex way. Due to the Buddhist influence, many new concepts and methods were introduced to China; in the epistemological sense, perhaps the most important one was the differentiation or the binary category of the subject (neng 能) and the object (suo 所) of comprehension. These new concepts led to a polarization of epistemology which also manifested itself in the methods of comprehension. Neo-Confucian philosophy presents two epistemological currents. Both were based upon different portions of The Book of Rituals (Li ji 禮記), which is part of the classical Confucian canon. The first one, whose most important representative is $\mathrm{Zhu} \mathrm{Xi}$ 朱喜 (1130-1200), is usually denoted as “objective idealism", the second one, which was developed almost three centuries later by Wang Shouren, belongs to "subjective idealism".

$\mathrm{Zhu} \mathrm{Xi}^{7}$, whose thought was partly based upon the ideas of his forerunners Han Yu 韓愈, Zhou Dunyi 周敦頣, and Cheng Yi 程頣, but developed much further in an extremely innovative way, established a new, highly influential upgrading of the traditional method of "investigating things (gewu 格物)", which was intrinsically connected to the concept of "ultimate knowledge (zhizhi 致知)".

${ }^{6}$ Classical Confucianism has long been an important pillar of Chinese culture, exerting a deep influence upon the societies of traditional China. But from the 12th century onwards, Neo-Confucianism became not only the intellectual mainstream in China, but also a representative of East Asian civilization as a whole and a common intellectual resource within the Sinograph cultural sphere, see LIN, Y. Lê Quý Đôn's Theory of Li-Qi. In Asian Studies, 2020, Vol. 8, No. 2, p. 52 [online] [cit. 3 June 2020]. Available from https:// doi.org/10.4312/as.2020.8.2.51-77.

7 “Zhu Xi 朱喜 $(1130-1200)$ is one of the most eminent Chinese philosophers, the figurehead of the Neo-Confucian school that in the eleventh century, after several centuries of Buddhist and Daoist prominence, tried to revive ancient Confucianism, in a manner somewhat similar to the way in which the Renaissance in Europe a few centuries later returned to the ideas of Greco-Roman Antiquity", see OTT, M. Deleuzian (Re)interpretation of Zhu Xi. In Asian Studies, 2020, Vo. 8, No. 2 p. 282 [online] [cit. 20 May 2019]. Available from https://doi.org/10.4312/as.2020.8.2.281-310. 
Indeed, in this view, the highest or most comprehensive form of knowledge could only be obtained by investigating the objects of external reality (gewu zhizhi 格 物致知). This is also the reason why this method is often described as a method of "objective idealism". It is tightly connected to the entire system of his rational philosophy, which was based upon the dynamic differentiation between the principle of structural coherence ( $l i$ 理) and its binary opposition of vital potential ( $q i$ 氣).

After Zhu Xi, Wang Shouren is usually viewed as the most significant NeoConfucian philosopher, whose interpretations of Confucianism were often based upon latent Buddhist (especially Chan Buddhist) influences, and mostly rejected Zhu Xi's orthodox philosophy and his rationalist binary differentiations. Wang's holistic alternative to such a rationalistic worldview was most clearly visible precisely in his ethico-epistemology, in which knowledge was comprehensively permeated with moral values.

\section{Life, Work and Influence}

Wang Shouren (1472 - 1529), who is also widely known under his pseudonym Wang Yangming 王陽明 belongs to the most famous and interesting philosophers from the Ming Dynasty $(1368-1644)$ period. Originally, Yangming 陽明 (which literally means "sunshine") was the name of the cave where he established his school and taught his disciples, so that he came to be known as “The Teacher of Sunshine” (Yangming xiansheng 陽明先生); the name stuck and many people are still unaware that this was not his real name. In his philosophical system, which contemporary Chinese scholars define as subjective idealism (in contrast to Zhu Xi's philosophy, which is considered as objective idealism), Wang Shouren primarily elaborated upon certain paradigms which had been formulated more than two hundred years previously by Lu Jiuyuan 陸九淵. While Wang's importance during the Ming dynasty was comparable to that of Zhu Xi during the Song dynasty, Wang left far fewer major, influential texts than his famous predecessor, and Zhu Xi's teachings on the structural principles of coherence (lixue 理學) had an incomparably greater political influence, and would form the basis of the official state doctrine in China until the beginning of the 20th century. As already mentioned, $\mathrm{Zhu} \mathrm{Xi}$ also developed the epistemological method of "investigating things" (gewu 格物) that was rooted in rational understanding of the objects of the external world. In contrast to such a theory of knowledge, Wang developed an intuition-based epistemology of innate knowledge (liangzhi 良知) that was based upon inherent a-priori forms of innate 
understanding. In the framework of the traditional Chinese theory of knowledge, he is also famous for his ideas regarding the unification of theory and practice or knowledge and action (zhixing heyi 知行合一).

Wang Shouren's family belonged to the class of officials and landlords. In addition to receiving a Confucian and, more particularly, a Neo-Confucian education in his youth, Wang also dedicated himself to a profound and extensive study of Daoist and Buddhist texts, something which was quite common in the upper classes at that time. At the age of twelve, he wrote a letter to the Emperor in which he criticized the latter for China's state of crisis and made numerous suggestions as to how things could be improved. Luckily, his father discovered the letter and prevented him from actually sending it. As a youth, Wang also showed great interest in the martial and military arts which, given the turbulent political situation of China at that time, was likewise a common feature of an aristocratic education, which naturally also included Buddhist thought and daily exercises in meditation. ${ }^{8}$

However, Wang Shouren did not gain his military reputation battling external enemies (which China certainly did not lack at that time), but due to his role in suppressing a number of local rebellions, something which may have carried over into his philosophy with his compelling concern for integrity and totality. ${ }^{9}$ While his feats on the battlefield ${ }^{10}$ brought honour, prestige and substantial political and financial benefits for himself and his family, he was far less successful as a philosopher, and had to defend his teachings against accusations of heresy. His rivalry with the influential eunuch Liu Jin 劉僅 in 1506 led to his being banished for three years to a remote area of the present-day province of Guizhou 貴州, which was also being ravaged by a fever epidemic during that time. However, Wang survived all of Lu Jin's attempts to eliminate him and upon his return to the capital rose to even greater heights of power and prestige.

In terms of philosophy, Wang is best known for his theory of knowledge, in which he treats the categories of "innate knowledge (liangzhi 良知)" and the "unity of knowledge and action (zhixing heyi 知行合一)", ${ }^{11}$ and his commentaries on the "Five Classics 五經” and the “Great Learning 大學”. His collected works were published soon after his death in thirty-eight volumes under

\footnotetext{
${ }^{8}$ BAUER. W. Geschichte der chinesichen Philosophie, p. 278.

${ }^{9}$ FORKE, A. Geschichte der neueren chinesichen Philosophie, Vol. III, pp. 384-388; XIA, Z. Zhongguo renshilun sixiang shigao, xia 中國認識論思想史稿, 下 [An Outline of the History of Chinese Epistemology, Part 2], pp. 218-220.

${ }^{10} \mathrm{He}$ even became Minister of War in 1522.

${ }^{11}$ XIA, Z. Zhongguo renshilun sixiang shigao, xia 中國認識論思想史稿, 下 [An Outline of the History of Chinese Epistemology, Part 2], p. 218.
} 
Wang Shouren's Ethico-Epistemology and the Double Nature of Recognition

the title "The Entire Collection of the Works of Sir Wang Wencheng" (Wang Wencheng Gong quan ji 王文成公全集).

\section{Ethico-Epistemology and the Crucial Position of the Heart-Mind}

Wang's philosophy provides a crucial node in the inextricable link between Chinese epistemology and ethics, something which is especially evident in the main concepts of his epistemological system: beside the aforementioned concepts of innate knowledge (liangzhi 良知) and the unity of knowledge and action (zhixing heyi 知行合一); his somewhat unorthodox interpretation of the idea of heart-mind (xin 心) also deserves our attention. Actually, the heart-mind is placed at the very centre of Wang's philosophy and his ethico-epistemology. $\mathrm{He}$ described the central function of this notion in the following famous passage:

The master was strolling over Nanzhen, when a friend showed him a blossoming tree on the mountaintop and asked him: 'If there is nothing outside of our mind, how can that blossoming tree on the mountain bud and fade all by itself, without any relation to our mind?' The master replied: 'Before you caught sight of these blossoms, they existed in your mind only in the form of deepest seclusion, but the moment you saw them, they immediately exploded in their brightest colours. So you can see that there are no blossoms outside your mind. ${ }^{12}$

先生遊南鎮, 一友指巖中花樹問曰, 天下無心外之物, 如此花樹在深山 中, 自開自落, 於心亦何相關, 先生曰, 爾未看此花時, 此花與爾心同歸 於寂, 爾來看此花時, 則此花顏色, 一時明白起來, 便知此花不在爾的心 外。

In this instance, Wang Shouren was following certain paradigms that had been established two centuries before by Zhu Xi's philosophical rival, the aforementioned scholar Lu Jiuyuan. Wang's idealism, however, was also fairly radical. When it comes to the recognition of reality, this idealism manifests itself in his specific understanding of perception, for he emphasized that nothing existed outside the human consciousness:

${ }^{12}$ WANG, S. Wang Wencheng Gong quan shu 王文成公全書 [The Complete Works of Sir Wang Wencheng], Vol. III, Yulu san, Chuanxi lu xia, p. 18. 
There are no principles, no things outside the heart-mind. ${ }^{13}$ 無心外之理, 無心外之物。

This heart-mind, which was a kind of morally aware consciousness, was consequently seen as the essence and basis of all existence and it manifested itself not only at the level of the individual mind, but also of the entire cosmos, where it appeared as the Neo-Confucian concept of primary, all-embracing structural principles ( $l i$ 理) that brought to life and determined all that exists.

The master said that mind is the principle. ${ }^{14}$

先生曰, 心即理也。

According to Wang, heart-mind provides us with a kind of consciousness which is not only the foundation of perception, but also the basis of comprehension, i.e. of cognitive interpretations of reality and, thus, of the very existence of that which is "real" within the physical world.

The mind produces meanings; the substance of meanings is knowledge and the realizations of meanings are concrete things. ${ }^{15}$

心之所發便是意, 意之本體便是知, 意之所在便是物。

The heart-mind is also the basis of vitality, because without it our bodies would be inanimate.

The master said: the ears, eyes, mouth, nose and the four extremities form the body. But without the heart-mind, how could anyone be able to see, hear, speak or move? ${ }^{16}$

先生曰: 耳目口鼻四肢身也, 非心安能視聽言動.

However, Wang acknowledges that it could not exist without the physical body.

But without the ears, eyes, mouth, nose and the four extremities our mind could neither see or hear, nor it could speak or move. ${ }^{17}$

心欲視聽言動, 無耳口目口鼻四肢亦不能。

${ }^{13}$ WANG, S. Yangming xiansheng jiyao 陽明先生集要 [A Collection of the Most Important Works of Sir Yangming], Vol. I, p. 8b.

${ }^{14}$ Ibid., p. 3a.

${ }^{15}$ WANG, S. Yangming xiansheng jiyao 陽明先生集要 [A Collection of the Most Important Works of Sir Yangming], Vol. I, p. 8b.

${ }^{16}$ Ibid., Vol. II, p. 2 a.

${ }^{17}$ Ibid. 
Wang Shouren's Ethico-Epistemology and the Double Nature of Recognition

Thus, for Wang, the physicality of our bodies was the bearer of meaning and sense, but simultaneously, he firmly denied the possibility of its existence outside of the ideal sphere of heart-mind. As opposed to the correlatively binary structured foundations of the Neo-Confucian realists, this sphere was absolutely primary for Wang Shouren.

Hence, without heart-mind there can be no body, and without body there can be no heart-mind. Nevertheless, we name the one that fulfils, body, and the one that rules, heart-mind. ${ }^{18}$

故無心則無身, 無身則無心, 但指其充塞處言之, 謂之身, 指其主 宰之處言之, 謂之心.

This was expressed even more clearly in his description of the basic substantial structure of the sense organs:

The eye as such does not have any physical substantiality; its physical substantiality is composed of the colours of everything that exists. The ear as such does not have any physical substantiality; its physical substantiality is composed of the sounds of everything that exists. The nose as such does not have any physical substantiality; its physical substantiality is composed of the smells of everything that exists. The mouth as such does not have any physical substantiality; its physical substantiality is composed of the flavours of everything that exists. The mind as such, likewise does not have any physical substantiality; its physical substantiality is composed of the sensation of true and false in heaven and earth and in everything that exists. ${ }^{19}$

目無體, 以萬物之色為體, 耳無體, 以萬物之聲為體, 鼻物體, 萬 物之 臭為 體, 口物體, 以萬物之味為體, 心物體, 以天地萬物感應 是非為體。

\section{Methods and Principles of Acquiring and Applying Knowledge}

This kind of 'cosmic subjectivism' also appears in the methods of comprehension that he developed on this basis. He adamantly rejects any proto-scientific procedures, such as the Neo-Confucian process of the 'Exploration of things (gewu 格物)', which long before Zhu Xi had been advocated by one of the earliest

\footnotetext{
18 Ibid.

${ }^{19}$ Wang Wencheng Gong quan shu 王文成公全書 [The Complete Works of Sir Wang Wencheng], Vol. III, Chuanxi lu xia, p. 18
} 
founders of realistic currents in Neo-Confucianism, Shao Yong 郡雍. According to Wang, genuine comprehension can be reached exclusively by the method of introspective reflection (fanguan 反觀):

The heart-mind is identical with Dao, and Dao is identical with Nature. If we know our heart-mind, we know Dao and hence Nature. ${ }^{20}$

心即道, 道即天, 知心則知道, 知天。

Since the human body was seen as the primary seat of the human heart-mind, this method has unavoidably led to knowledge that was rooted in bodily recognition (tiren 體認):

By following our very heart-mind, we can gain bodily recognition. This cannot be achieved by unfilled searching outside of it. (The heart-mind) is the beginning (of bodily recognition). ${ }^{21}$

順從自己心上體認, 不假外求, 始得。

Every person thus possesses original, natural, innate knowledge (liangzhi 良 知), which is the only possible proper and true understanding:

There is no knowledge outside of innate knowledge. ${ }^{22}$ 良知之外便無知。

In Wang's theory, this inborn quality is ethical in nature; it cannot be detached from the feeling of empathy for all other human beings and hence it is tightly linked to the crucial Confucian virtue of humanness (ren 仁). ${ }^{23}$ At the same time, liangzhi is also an inseparable part of the human mind:

The heart-mind is the ruler of the body; its immaterial wisdom and clarity is called innate knowledge, which is elementary in itself". ${ }^{24}$

心者身之主也而心之虛靈明覺即所謂本然之良知也。

${ }^{20}$ WANG, S. Yangming xiansheng jiyao 陽明先生集要 [A Collection of the Most Important Works of Sir Yangming], Vol. I, p. 30a.

${ }^{21}$ Ibid.

${ }^{22}$ Ibid., Vol. IV, p. 82b.

${ }^{23}$ HUANG, Y. 'Empathy for Devils': What We Can Learn from Wang Yangming. In MI, Ch., SLOTE, M., SOSA, E. (ed). Moral and Intellectual Virtues in Western and Chinese Philosophy, pp. 216-217.

${ }^{24}$ WANG, S. Wang Wencheng Gong quan shu 王文成公全書 [The Complete Works of Sir Wang Wencheng], Vol. III, Chuanxi lu xia, p. 20. 
Wang Shouren's Ethico-Epistemology and the Double Nature of Recognition

Like the heart-mind, of which it is a part, innate knowledge is also ordered in accordance with the basic structure of nature or heaven (tianli 天理):

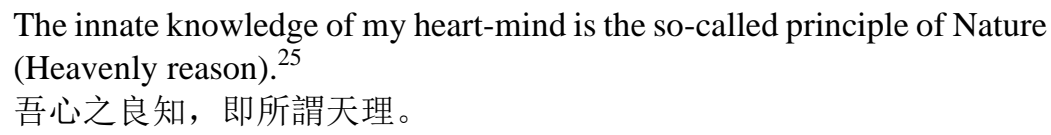

This basic epistemological concept also forms the foundation of Wang's ethic in the sense of moral recognition, or the distinction between good and evil. Therefore, his theory is ethico-epistemological. The inseparability of morality and knowledge, which manifests itself in the concept of liangzhi, can thus be clearly seen in numerous passages of Wang's work:

The recognition of good and evil is innate knowledge. ${ }^{26}$ 知善知惡是良知。

Innate knowledge is the heart-mind's awareness of true and false, and true and false is nothing other than good and evil. ${ }^{27}$

良知只是個是非之心，是非只是個好惡。

The heart-mind's awareness of true and false cannot be achieved through reasoning, nor can it be learned. That is why it is called innate knowledge. ${ }^{28}$ 是非之心, 不待慮而, 不待學而能, 是故謂之良知。

As we can see, innate knowledge represents the basic criterion for the recognition and evaluation of individual comprehension, as well as of social interactions. In many respects, this criterion recalls the Christian concept of conscience. ${ }^{29}$

This point of innate knowledge is your very personal compass, which gives meaning to everything. When it tells you that something is true, you may

\footnotetext{
${ }^{25}$ Ibid., Vol. II, Chuanxi lu zhong, Da Lu Yuan jing shu, p. 57.

${ }^{26}$ Ibid., Vol. III, Chuan xi lu xia, p. 26.

${ }^{27}$ WANG, S. Wang Wencheng Gong quan shu 王文成公全書 [The Complete Works of Sir Wang Wencheng], Vol.I II, Chuan xi lu xia, p. 20.

${ }^{28}$ Ibid., Vol. XXVI, Da xuewen, p. 29.

${ }^{29}$ The etymology of the first character in this phrase (liang 良) is '(moral) goodness' The modern Chinese word which expresses 'conscience' (liang xin 良心) is also composed of the same character, together with the term xin ', which means 'heart', or, in the interpretative context of Neo-Confucian idealism, 'heart-mind'.
} 
know that it is true indeed, and when it tells you that something is false, you may know that it is false indeed. You can never deceive it; therefore, it is best to remain honest and to follow it. In this way, you will preserve good and abandon evil. It will thus offer you steadiness and joy. If you cannot rely on this genuine impulse, you will never be able to explore anything. ${ }^{30}$

爾那一點良知, 是爾自家底準則, 爾意念之處, 他是便知是, 他非 便知非, 便瞞他一些不得, 爾只不要欺他, 實實落落依著他, 善便存, 惡便去, 他這裡何等穩當快樂。。。若不靠著這些真機, 如何去格物.

Since Neo-Confucian ideology is based on the Mencian interpretation of ancient Confucianism, this unity of innate knowledge and moral goodness is quite unsurprising. Therefore, Wang pointed out that Mencius 孟子, as opposed to Xunzi 荀子, stressed the goodness of human nature:

Knowledge is the substance of heart-mind. The mind knows by itself, which is why you will naturally feel piety whenever you see your father and you will naturally feel brotherly love whenever you see your brother. This is innate knowledge, which we do not have to search for outside ourselves. ${ }^{31}$

知是心之本體, 心自然會知, 見父自然會孝, 見兄自然會弟。此便 是良知, 不假外求。

Thus, in a certain sense, Wang's theory is an epistemological broadening and elaboration of this Mencian idea and, in fact, Wang often cites Mencius directly, as in the following passage:

'All men possess a heart-mind, which is able to distinguish true from false (good from evil)'. This is innate knowledge. ${ }^{32}$

是非之心, 人皆有之 ${ }^{33}$, 即所謂良知也。

${ }^{30}$ WANG, S. Wang Wencheng Gong quan shu 王文成公全書 [The Complete Works of Sir Wang Wencheng], Vol. II, p. 4b.

${ }^{31}$ Ibid., Vol. I, p. 9a.

${ }^{32}$ Ibid., Vol. V, Yu Lu Yuan jing, pp. 85-86.

${ }^{33}$ The first part of this quotation was borrowed from Mencius 孟子, s.d. Gaozi I, 6. 


\section{From Innate Knowledge to the Unity of Knowledge and Action}

Innate knowledge, however, is not merely a passive substance of ethical comprehension. Through the process of "successful" introspection, it also automatically leads to "proper" (and, thus, morally good) action, and can therefore provide a criterion for our behaviour. Here, Wang, obviously influenced by Chan Buddhism, tried to expand upon the Mencian theory, stressing that the notions of good and evil are not absolute concepts, since all that exists is regulated in accordance with the all-embracing and all-encompassing structure of the natural order of cosmic reason, which is dynamic and constantly alternating:

Originally, the fundamental substance of humaneness was neither good nor evil. In terms of its functioning, it could originally perform either good or evil actions. ${ }^{34}$

性之本體, 原是無善無惡的, 發用上, 也原是可以為善, 可以為惡 的。

According to Wang Shouren, good and evil cannot be separated from human 'intention' (yinian 意念). Hence, human action can only be evaluated in the context of specific concrete situations. ${ }^{35}$ The impulse which tells us what is right ( $s h i$ 是) or wrong ( $f e i$ 非) in a particular situation is, once again, the concept of innate knowledge (liangzhi 良知):

The substance of mind is neither good nor evil. Good and evil are directed by intentions. Knowing good and knowing evil is innate knowledge; doing good and eschewing evil are exploring things. ${ }^{36}$

無善無惡, 是心之體, 有善有惡, 是意之動, 知善知惡, 是良知, 為善去惡，是格物。

\footnotetext{
${ }^{34}$ WANG, S. Yangming xiansheng jiyao 陽明先生集要 [A Collection of the Most Important Works of Sir Yangming], Vol.II, p. 29a.

${ }^{35}$ We should recall that the prevailing criterion for regulating and sanctioning human interaction in the Confucian tradition was never understood or established as a normative standard in the sense of Western legislation. In Confucian state doctrine, this criterion was never established as a fixed, absolutely defined "law", which was equally valid for everybody, but as a flexible concept of "rituality" ( $l i$ 禮) that was dependent upon the specific circumstances of actual, concrete situations.

${ }^{36}$ WANG, S. Yangming xiansheng jiyao 陽明先生集要 [A Collection of the Most Important Works of Sir Yangming], Vol. II, p. 32a.
} 
From this premise, Wang proceeded to the unity of knowledge and action (zhixing heyi 知行合一):

When we search for principles outside of the mind, we find that knowledge
and action are two different things. But if we search for the principles
within our own mind, we will find the sacred teaching of the unity of
knowledge and action. 37
外心以求理, 此知行之所以為二也, 求理於吾心, 此聖門知行合一之教。

The unity of knowledge and action is thus a touchstone for Wang, in order to ascertain whether or not certain recognition truly arose from 'innate knowledge':

There is no knowledge without action. To know and not to act, means not to know. ${ }^{38}$

未有知而不行者, 知而不行, 只是未知。

Before Wang Shouren, the binary category of knowledge and action and the question of the relation between these two concepts represented one of the fundamental problems of classical Chinese epistemology. But in his work, 'innate knowledge', in which the boundary between knowledge and action apparently disappears, had the nature of some kind of instinct. Nevertheless, even after Wang Shouren the debate on the relation between knowledge and action still remained a crucial issue, something which indicates the distinctively elementary character of Chinese philosophy. In fact, until only recently, philosophers were still divided on the seemingly simple question of whether knowledge or action was of primary importance. ${ }^{39}$

Wang explained why and in which way these two elements of recognition exist in mutual complementarity. They are interdependent and complement one another. With this idea he apparently solved this old dilemma in a simple and concise, but elegant, way. His holistic response to the question of knowledge and action is typical of the majority of his philosophical precepts, while also defining the entire ethical foundation of the ethico-epistemology of the School of HeartMind (Xin xue 心學):

${ }^{37}$ WANG, S. Wang Wencheng Gong quan shu 王文成公全書 [The Complete Works of Sir Wang Wencheng], Vol. II, Chuanxi lu zhong, Da Gu Dongqiao shu, p. 40.

${ }^{38}$ WANG, S. Yangming xiansheng jiyao 陽明先生集要 [A Collection of the Most Important Works of Sir Yangming], p. $6 \mathrm{a}$.

${ }^{39}$ BAUER, W. Geschichte der chinesichen Philosophie, p. 281. 
Wang Shouren's Ethico-Epistemology and the Double Nature of Recognition

Knowledge is the beginning of action, and action is the result of knowledge. ${ }^{40}$

知是行之始, 行是知之成。

\section{Impact upon Later Developments: the Controversy between Gradualism and Subitism}

Despite the significance of such ideas, Wang's theories still remained controversial, and some aspects of his thought are still the subject of heated debates. One such aspect can certainly be found in the very innovative, but also rather risky, tenet of Wang Yangming's philosophy, that manifests itself in his exposition of the absence of the absolute validity of good and evil. Indeed, while his deviation into the ideal space beyond good and evil signified a negation of the Confucian determinism of concrete ethical principles, it was also the clearest indication of the impact of Buddhist and Daoist elements, which would then enter, even if only indirectly and implicitly, into the idealistic streams of NeoConfucianism precisely through Wang's philosophy.

Nevertheless, this premise became the very rock upon which the spirit of his followers would break apart. This difficulty had already become visible shortly before Wang's death, i.e. in the famous dialogue between his two disciples, Qian Dehong 錢德洪 and Wang Ji 王畿, which has come down to us with the title Enlightenment at the Heavenly Spring (Tian quan zheng wu 天泉證悟 ). ${ }^{41}$ The topic of the debate was this particularly troublesome aspect of Wang's teachings, for as we can see below, he explicitly denied the very existence of good and evil as such. In his view, they were only parts of human intentions and had therefore to be seen as merely ideational constructs, pertaining to ethics:

The substance of heart-mind is neither good nor evil. Good and evil are directed by intentions. Innate knowledge provides us with the understanding of good and evil. Exploring things means to do good and banish evil. ${ }^{42}$

\footnotetext{
${ }^{40}$ WANG, S. In XIA, Z. Zhongguo renshilun sixiang shigao, xia 中國認識論思想史稿, 下 [An Outline of the History of Chinese Epistemology, Part 2], p. 245.

${ }^{41}$ The dialogue took place on the bridge above the Heavenly Spring, which was purportedly situated in the present-day province of Guangxi, see BAUER, W. Geschichte der chinesichen Philosophie, p. 284.

${ }^{42}$ WANG, S. Wang Wencheng Gong quan shu 王文成公全書 [The Complete Works of Sir Wang Wencheng], Vol. III, Chuanxi lu xia, p. 26.
} 
Asian and African Studies, Volume 30, Number 2, 2021

\section{無善無惡是心之體, 有善有惡是意之動, 知善知惡是良知, 為善去 惡是格物。}

Not quite sure about the actual meaning of this idea, both of his most talented disciples discussed it first among themselves. As we can see in Wang's collected works, in which this debate was recorded, each of them understood the statement in a different way:

- Dehong asked: - 'What does it mean?'

- Wang $\mathrm{Ji}^{43}$ replied: 'I think that this is not the end of this proverb, for if the substance of heart-mind is neither good nor evil, then the intentions cannot be good or evil either. In this case, there can be no good or evil in knowledge, nor in things or beings. But if we presuppose that there is good and evil in intentions, then the same should hold true for the substance of mind'.

- Dehong said: 'The substance of mind is the nature of the universe, in which originally there was no good or evil. But people also possess the habituated mind, and therefore their intentions are good or evil. Only through the complete exploration of things and the sincere cultivation of proper actions can one gradually return to this original stage, in which there is no good or evil. Needless to say, this is a question of exercise' ${ }^{44}$ 德洪曰: ‘此意如何? 汝中曰: ‘此恐未是究竟話頭。若曰心體是無善 無惡, 意亦是無善無惡的意, 知意是無善無惡的知, 物亦是無善無 惡的物。若說意有善惡, 畢竟心體還有善惡在’。德洪曰: ‘心體是天 命之性, 原是無善無惡的, 但人有習心，意念上見有善惡在，格， 致，誠正，修此正是復那性體功夫若原無善無惡，功夫亦不消說矣 ‘。

According to the same source ${ }^{45}$, both disciples met their master on the bridge over the Heavenly Spring that very same evening, and they asked him to give them the correct interpretation of the supposition. Wang told them that he was going to leave that same evening, so it was important to explain his idea to them before departure. First, he emphasized that both of their interpretations were correct. They were not in mutual contradiction; on the contrary, they even complemented one another. However, on the other hand, none of them was

${ }^{43}$ Here, Wang Ji is identified by his nickname Ru Zhong 汝中, see FORKE, A. Geschichte der neueren chinesischen Philosophie, Vol. III, p. 414.

${ }^{44}$ WANG, S. Wang Wencheng Gong quan shu 王文成公全書 [The Complete Works of Sir Wang Wencheng], Vol. III, Chuanxi lu xia, p. 27.

${ }^{45}$ See Ibid. 
universally valid, for they applied to different contexts. ${ }^{46}$ Wang tried to explain it in the following way:

Each of them corresponds to a certain type of person. On the one hand, there are people who possess the quality of favourable roots ${ }^{47}$. This kind of person can directly and spontaneously experience the most elementary recognition of the substance of the mind; they can immediately comprehend it in its totality, down to the last details. On the other hand, many people do not possess such a quality yet. They need a lot of exercise and practice to acquire comprehension. Only with practice and exercise can they experience the unity of the inner and outer world. The substance of their mind is covered by layers of common habits, and therefore they need to be taught how to perform good and avoid evil in their actions. Through constant practice, such persons will mature in their actions and thus be able to gain the full and clear recognition of the basic substance of being..$^{48}$

我這裡接人原有此二種利根之人直從本原上悟入人心本體原是瑩澄 無滯的, 原是個未發之中利根之人一悟本體即是功夫, 人即內外一 齊俱透了。其次不免有習心在, 本體受蔽, 故且教在意念上實落為 善去惡, 功夫熟后, 渣滓去去得盡時, 本體亦明淨了。

In Wang's view, Wang Ji's interpretation corresponded to the former, and Dehong's to the latter kind of person. Since he believed they were complementary, it was important to him that both kinds of learning should be taught in future. Therefore, he did not want his disciples to persist in only one method, since neither of their interpretations represented the one and only truth, valid for everybody. It is quite obvious that for him, this relativity of the basic methods of perception, recognition and understanding was of utmost importance. Hence it cannot be coincidental that before leaving, he urged them once again not to forget this teaching. ${ }^{49}$

${ }^{46}$ WANG, S. Ibid., p. 27.

47 This expression (li gen 利根 = favourable roots) is originally a Buddhist term; the word 'roots' originally referred to connections with knowledge and recognitions, which had been acquired during previous lives.

${ }^{48}$ WANG, S. Wang Wencheng Gong quan shu 王文成公全書 [The Complete Works of Sir Wang Wencheng], Vol. III, Chuanxi lu xia, p. 27.

49 Ibid. 


\section{Conclusion}

Because Wang Shouren died soon afterward, this was the last conversation the two disciples would have with their master. The record of this conversation is very illustrative, since it already indicates the subtle boundary between instant and gradual recognition, which would later on profoundly characterize both main currents of future Neo-Confucian epistemology.

In the debate on the nature or method of enlightenment (or salvation) this boundary is also of great importance for Chinese Buddhism, and analogously, also for syntheses between Buddhist and Confucian philosophies. Indeed, it is quite clear that this controversy between gradualism and subitism in epistemology originated in Chan Buddhist debates on instant and gradual enlightenment or salvation, which took place many centuries earlier. Hence, its appearance in the context of Wang Shouren's school still bore distinctly - albeit hidden and latent - Buddhist features.

Taking this fact into account, the above-mentioned debate and Wang's interpretation of the double nature of recognition argue in favour of the supposition according to which Wang Shouren was strongly influenced by Chan Buddhism. As Wing-Tsit Chan notes, such assumptions are somewhat too hasty because it is not generally realized that he had less contact with Buddhism than is generally suspected, and that he was more critical of Buddhism than he was receptive of it. ${ }^{50}$ We must not forget that Wang often criticized the illusionary nature of the Buddhist view of reality. Being a Confucian, he firmly believed that striving for individual salvation points to a "selfish mind". ${ }^{51}$

Wang's ethico-epistemology points in a very different direction. Regardless of the actual ontological status of good and evil, the human heart-mind, which encompasses both the epistemology of innate knowledge and the method of unity of knowledge and action, is always related to humanness (ren 仁). Therefore, it is always necessarily directed toward enhancing social empathy, ${ }^{52}$ and increasing common well-being in human communities. For Wang, we live in a shared world and should therefore strive for an ethically meaningful life in the realm of here and now, and not beyond it in an empty, timeless space of transcendent reality.

${ }^{50}$ CHAN, W. How Buddhistic Is Wang Yang-Ming? In Philosophy East and West, 1962, Vol. 12, No. 3, p. 203.

${ }^{51}$ Ibid.

${ }^{52}$ See HUANG, Y. 'Empathy for Devils': What We Can Learn from Wang Yangming. In MI, Ch., SLOTE, M., SOSA, E. (ed). Moral and Intellectual Virtues in Western and Chinese Philosophy, p. 216. 


\section{Acknowledgement}

The author acknowledges the support of the Slovenian Research Agency (ARRS) in the framework of the research core funding Asian Languages and Cultures (P60243) and in the scope of the research project N6-0161 Humanism in Intercultural Perspective: Europe and China.

\section{REFERENCES}

BAUER, Wolfgang. Geschichte der chinesichen Philosophie. München: C. H. Beck, 2000.

CHAN, Wing-Tsit. How Buddhistic Is Wang Yang-Ming? In Philosophy East and West, 1962, Vol. 12, No. 3, pp. 203-215.

FORKE, Alfred. Geschichte der neueren chinesichen Philosophie. Volume III. Hamburg: R. Oldenbourg, 1934.

GONG, Zhebin 宮哲賓. Zhongguo gudai zhexue you mei you renshi lun 中國古 代哲學有沒有認識論? [Does Classical Chinese Philosophy Contain a Theory of Knowledge?]. In Guangxi minzu xиeуuan xuebao, 1996, Vol. 96, No. 3, pp. 12-25.

HU, Xiangnong. The Relativity of Ren (Humaneness). In Asian Studies, 2021, Vol. 9, No. 1, pp. 181-201. https://doi.org/10.4312/as.2021.9.1.181-201

HUANG, Yong. 'Empathy for Devils': What We Can Learn from Wang Yangming. In MI, Chienkuo, SLOTE, Michael, SOSA, Ernest (ed.). Moral and Intellectual Virtues in Western and Chinese Philosophy. New York, London: Routledge, 2015. pp. 214-234.

LIAO, Xiaoping 翏小平. Lun Zhongguo chuantong zhexue daode renshilunde tezhi 論中國傳統哲學道德認識論的特質 [On special Features of Traditional Chinese Moral Epistemology]. In Hebei Xuekan, 1994, Vol. 94, No. 4, pp. 43-47.

LIAO, Xiaoping 零小平. Shilun xifang chuantong zhexue renshilunde jiben qubie 試論中西方傳統哲學認識論的基本区別 [Basic Differences between the Chinese and Western Theory of Knowledge]. In Jinyang xuekan, 1994, Vol. 94, No. 2, pp. 38-44.

LIN, Yueh-hui. Lê Quý Đôn's Theory of Li-Qi. In Asian Studies, 2020, Vol. 8, No. 2, pp. 51-77 [online] [cit. 3 June 2020]. Available from https://doi.org/10.4312/as.2020.8.2.51-77

Mengzi 孟子. s.d. In Chinese Text Project, Pre-Qin and Han [online] [cit. 12 December 2020]. Available from https://ctext.org/mengzi 
OTT, Margus. Deleuzian (Re)interpretation of Zhu Xi. In Asian Studies, 2020, Vo. 8, No. 2, pp. 281-310 [online] [cit. 20 May 2019] Available from https://doi.org/10.4312/as.2020.8.2.281-310

WANG, Shouren 王守仁. Yangming xiansheng jiyao 陽明先生集要 [A Collection of the Most Important Works of Sir Yangming], 12 Volumes. Shanghai: Shangwu yinshuguan, 1929.

WANG, Shouren 王守仁. Wang Wencheng Gong quan shu 王文成公全書 [The Complete Works of Sir Wang Wencheng]. Shanghai: Shangwu yinshuguan, 1933.

XIA, Zhentao 夏甄陶. Zhongguo renshilun sixiang shigao, xia 中國認識論思想 史稿, 下 [An Outline of the History of Chinese Epistemology, Part 2]. Beijing: Zhongguo renmin daxue chuban she, 1996. 